\title{
ANALISIS HISTORIS TERHADAP INTEGRASI KURIKULUM PENDIDIKAN ISLAM PADA MASA ABBASIYAH
}

\author{
Siti Farida \\ STAI Nazhatut Thullab Sampang \\ Email: faridaisme@gmail.com
}

\begin{abstract}
Abstrak:
Sejak awal kekuasaannya, Dinasti Abbasiyah sangat memperhatikan perkembangan pendidikan. Hamper diseluruh wilayah Islam berdiri berbagai macam lembaga pendidikan. Lembaga-lembaga tersebut tersebar di perkotaan dan perdesaan. Perkembangan lembaga pendidikan yang demikian maju pada masa Dinasti Abbasiyah telah disertai dengan penataan kurikulum yang baik. Ketika itu terdapat tiga jenis kurikulum di madrasahmadrasah: kurikulum pendidikan rendah, menengah dan kurikulum pendidikan tinggi. Kurikulum pendidikan rendah bentuknya bervariasi, tergantung pada tingkat kebutuhan masyarakat. Namun secara umum kurikulum yang diajarkan ketika itu adalah belajar membaca, menulis, tata bahasa, hadits, prinsipprinsip dasar matematika, dan syair. Selain itu ada pula yang menambahkan pelajaran nahwu dan cerita-cerita kepahlawanan Islam.bahkan ada kurikulum yang sebatas menghafal Al-Qur'an dan menkaji dasar-dasar ajaran Islam. Kurikulum pendidikan tinggi dibagi menjadi dua jurusan : jurusan ilmu-ilmu agama dan jurusan ilmu pengetahuan umum. Kurikulum agama terdiri dari fikih, nahwu, kalam, kitabah, dan lain-lain. Sedangkan kurikulum umum terdiri dari matematika, logika, ilmu angka-angka, geometri, astronomi, music, aritmatika, hukum-hukum geometri dan sebagainya.
\end{abstract}

Kata Kunci: Kurikulum, Abbasiyah

\section{Abstract:}

Since the beginning of his power, The Abbasid dynasty paid great attention to the development of education. Almost all Islamic regions stand a variety of educational institutions. These institutions are scattered in urban and rural areas. The development of such an educational institution advanced during the Abbasid period has been accompanied by a good curriculum arrangement. At that time there were three types of curriculum in Madrasahs: low, middle, and higher education curricula. The lower 
education curriculum varies in form, depending on the level of community needs. But in general the curriculum taught at the time was learning to read, write, grammar, hadith, basic principles of mathematics, and poetry. In addition there are also add nahwu lessons and Islamic heroic stories.bahkan there is a curriculum that is merely memorize the Qur'an and examine the basics of Islamic teachings. The higher education curriculum is divided into two majors: the majors of the religious sciences and the general science department. The religious curriculum consists of fiqh, nahwu, kalam, kitabah, and others. While the general curriculum consists of mathematics, logic, numerology, geometry, astronomy, music, arithmetic, geometry laws and so on.

Keywords: Curriculum, Abbasiyah

\section{Pendahuluan}

Pendidikan sebagai suatu sistem merupakan satu kesatuan dari beberapa unsur dalam rangka mencapai tujuan pendidikan yang diinginkan. Unsur-unsur tersebut saling berhubugan dan saling bergantung dalam mencapai tujuan. Salah satu unsur tersebut adalah kurikulum, baik kurikulum di zaman klasik maupun kurikulum modern.

Kurikulum dalam pendidikan Islam pada zaman dahulu tentunya tidak sama dengan kurikulum modern. Menurut Ahmad Tafsir, kurikulum adalah sejumlah mata pelajaran yang harus ditempuh atau dipelajari oleh siswa. Lebih luas lagi kurikulum bukan hanya sekedar rencana pelajaran, tetapi semua yang secara nyata terjadi dalam proses pendidikan di sekolah. ${ }^{1}$ Pada lembaga pendidikan saat ini, siswa dituntut untuk mempelajari sejumlah bidang studi yang ditawarkan oleh lembaga. Disamping itu, siswa juga diwajibkan mengikuti serangkaian kegiatan sekolah yang dapat memberikan pengalaman belajar.

Pada awal Islam, kurikulum yang terdapat di lembaga pendidikan Islam tidak menawarkan mata pelajaran yang bermacam-macam. Dalam suatu jangka waktu, pengajaran hanya penyajikan satu mata pelajaran yang harus ditempuh oleh siswa. Sesudah materi tersebut selesai, baru ia diperbolehkan mempelajari materi yang lain, atau yang lebih tinggi tingkatannya.

${ }^{1}$ Ahmad Tafsir, Ilmu Pendidikan dalam Perspektif Islam, (Bandung: Rosdakarya, 1992), 53 
Misalnya pada tahap awal siswa diharuskan belajar baca-tulis, berikutnya ia belajar berhitung dan seterusnya.

Kurikulum dalam lembaga pendidikan pada masa klasik pada mulanya berkisar pada bidang studi tertentu. Namun seiring perkembangan social dan kultural, materi kurikulum menjadi semakin luas. Pada masa Nabi di Madinah, materi pelajaran berkisar pada belajar menulis, membaca Al-Qur'an, keimanan, ibadah, akhlak, dasar ekonomi, dasar politik dan kesatuan. ${ }^{2}$

Setelah wilayah Islam semakin luas, Islam harus bersentuhan dengan budaya masyarakat non-Islam yang menyebabkan permasalahan social semakin komples. Problem social tersebut pada akhirnya berpengaruh besar terhadap kehidupan keagamaan dan intelektual Islam, termasuk ilmu Hellenistik yang terjalin kontak dengan Islam. Perkembangan kehidupan intelektual dan kehidupan keagamaan dalam Islam membawa situasi lain bagi kurikulum pendidikan Islam. Maka diajarkanlah ilmu-ilmu baru seperti Tafsir, Hadits, Fiqih, Tata Bahasa, Sastra, Matematika, Teologi, Astronomi dan Kedokteran. ${ }^{3}$

Selanjutnya, tulisan ini akan menganalisis bentuk kurikulum pada masa dinasti Abbasiyah dengan alasan bahwa pada masa dinasti Abbasiyah berada pada masa puncak kejayaan Islam dan ilmu pengetahuan berkembang dengan pesatnya.

\section{Pengertian Kurikulum}

Secara umum kurikulum diartikan sebagai mata pelajaran yang diajarkan di sekolah. Pengertian ini dianggap masih tradisional dan masih banyak dianut sampai sekarang. Dalam perkembangan kurikulum sebagai suatu kegiatan pendidikan, timbul berbagai difenisi lain. Seperti yang diungkapkanoleh Saylor dan Alexander sebagaimana dikutip M. Ahmad kurikulum sebagai "the total effort of the school to going about desired outcomes in school and out-of-school situation. ${ }^{4}$ Dari pengertian diatas kurikulum tidak hanya sekedar mata pelajaran, tetapi segala usaha sekolah untuk mencapai tujuan yang diinginkan, baik situasi di dalam sekolah maupun di luar sekolah.

Secara etimologi kurikulum berasal dari bahasaYunani "currere" yang mula-mulai digunakan dalam bidang olahraga yang berarti jarak tempuh lari. Dalam kegiatan berlari tentu saja ada

\footnotetext{
${ }^{2}$ Ahmad Tafsir, Ilmu Pendidikan dalam Perspektif Islam, (Bandung: Rosdakarya, 1992), 59

${ }^{3}$ Hanun Asrohah, Sejarah Pendidikan Islam, (Jakarta: Logos, 1999), 73

${ }^{4}$ M. Ahmad, Pengembangan Kurikulum, (Bandung: Pustaka Setia, 1998), 9
} 
jarak yang harus ditempuh mulai start sampai dengan finish. Jarak dari start sampai dengan finish ini disebut currere.

Istilah kurikulum semula berasal dari istilah dari dunia atletik yaitu currere yang berarti berlari. Istilah tersebut erat hubungannya dengan kata curier yang berarti penghubung seseorang untuk menyampaikan sesuatu kepada orang atau tempat lain. Seorang kurir harus menempuh suatu perjalanan untuk mencapai tujuan, maka istilah kurikulum kemudian diartikan sebagai jarak yang harus ditempuh. ${ }^{5}$

Dari istilah atletik, kurikulum mengalami pergeseran arti ke dunia pendidikan, misalnya pengertian kurikulum yang tercantum dalam Webster's International Dictionary "curriculum: course a specified fixed course of study, as in a school or college, as one leading to a degree".

Kurikulum diartikan sebagai sejumlah matapelajaran yang harus ditempuh dan dikuasai untuk mencapai suatu tingkat tertentu atau ijazah. Disamping itu, kurikulum juga diartikan sebagai suatu rencana yang sengaja dirancang untuk mencapai sejumlah tujuan pendidikan. Itulah sebabnya, pada masa klasik kurikulum disebut dengan istilah rencana pelajaran.

Konsep kurikulum berkembang sejalan dengan perkembangan teori dan praktik pendidikan dan banyak pakar pendidikan yang mendefinisikan kurikulum sesuai dengan aliran atau teori pendidikan yang dianutnya. Berikut ini adalah definisi kurikulum menurut para ahli pendidikan, yaitu:

Menurut John Dewey dalam S. Nasution6 kurikulum merupakan suatu rekonstruksi berkelanjutan yang mamaparkan pengalaman belajar anak didik melalui suatu susunan pengetahuan yang terorganisasikan dengan baik. Menurut Raph Tyler kurikulum adalah seluruh pengalaman belajar yang direncanakan dan diarahkan oleh sekolah untuk mencapai tujuan pendidikan.

Menurut Hilda Taba kurikulum adalah pernyataan tentang tujuan-tujuan pendidikan yang bersifat umum dan khusus dan materinya dipilih dan diorganisasikan berdasarkan suatu pola tertentu untuk kepentingan belajar dan mengajar.

Menurut Robert Gagne kurikulum adalah suatu rangkaian unit materi belajar yang direncanakan sedemikian rupa sehingga anak didik dapat mempelajarinya berdasarkam kemampuan awal yang dimilliki/dikuasainya.

\footnotetext{
${ }^{5}$ S. Nasution, Pengembangan Kurikulum , (Bandung: Citra Aditya, 1993), 5 ${ }^{6}$ Ibid, 5
} 
Dari definisi diatas, dapat disimpulkan bahwa kurikulum itu berisi bahan yang disajikan (materi pelajaran), pengalaman belajar, tujuan yang ingin dicapai, kegiatan pengajaran dan rencana yang terorganisir.

\section{Bentuk-Bentuk Kurikulum}

Para pendidik berbeda pendapat tentang pola pengembangan kurikulum dan pola penyusunan materi pelajaran. Hal ini disebabkan adanya perbedaan pendapat mereka tentang tujuan, makna dan metode pendidikan. Dalam pengembangan kurikulum dan penyusunan materi pelajaran ada beberapa bentuk kurikulum, yaitu: Separate-Subject Curriculum, Correlated Curriculum Dan Integrated Curriculum. ${ }^{7}$

\section{Separate-Subject Curriculum}

Kurikulum yang disusun dalam bentuk ini menyajikan bahan pelajaran dalam bentuk subjek-subjek atau mata pelajaran tertentu. Tiap mata pelajaran tersebut satu dengan yang lain bersifat terpisah-pisah dan tidak dikaitkan. Dalam kurikulum ini setiap materi pelajaran mempunyai eksistensi sendiri dengan perangkat pengetahuan yang benar-benar terpisah dari materi dan pengetahuan yang lain.

Kurikulum yang disusun dalam bentuk terpisah-pisah itu lebih bersifat subject-centered, berpusat pada bahan pelajaran dan mengabaikan minat dan keinginan siswa. Kurikulum ini disusun berdasarkan teori habitus, yang beranggapan bahwa keperibadian siswa itu dapat terbentuk berdasarkan potongan-potongan pengetahuan. Berdasarkan pandangan tersebut, kepribadian yang utuh dapat dibentuk berdasarkan sejumlah pengetahuan yang diperoleh secara terpisah.

\section{Correlated Curriculum}

Bentuk kurikulum ini dibuat bedasarkan sebuah pandangan psikologis yang menggantikan teori sebelumnya dan munculllah teori asosiasi. Menurut teori asosiasi bahwa akal manusia tersusun dari interkorelasi dan interaksi antar-berbagai pengetahuan, dan pengetahuan yang baru pasti bertalian dengan pengalaman dan pengetahuan terdahulu. ${ }^{8}$

Kurikulum dengan bentuk ini menyajikan berbagai materi pelajaran seakan-akan merupakan mata rantai yang saling

\footnotetext{
7 S. Nasution, Pengembangan Kurikulum , (Bandung: Citra Aditya, 1993), 80

8 Abdurrahman An-Nahlawi, Prinsip-Prinsip dan Metode Pendidikan Islam, (Bandung: CV. Diponegoro, 1992), 271
} 
terkait.setiap mata rantai darinya harus bertalian dengan yang sebelumnya atau dibangaun atas suatu rantai yang sebelumnya. Oleh sebab itu dalam setiap pengajaran terlebih dahulu harus dimulai dengan mengingat kembali pelajaran-pelajaran yang telah lalu.

\section{Integrated Curriculum}

Berbeda halnya dengan kurikulum bentuk correlated subject yang hanya menghubungkan antara beberapa mata pelajaran yang masing-masing masih mempertahnkan efisiensinya, kurikulum bentuk intregated ini benar-benar menghilangkan batas-batas di antara berbagai mata pelajaran ini. Mata pelajaran itu dilebur menjadi satu keseluruhan dan disajikan dalam bentuk unit. Misalnya mata pelajaran ekonomi, sosiologi, antropologi, geografi, sejarah dilebur menjadi satu mata pelajaran yaitu pelajaran ilmu pengetahuan sosial.

\section{Dinasti Abbasiyah}

Kekuasaan dinasti Bani Abbas atau khilafah Abbasiyah melanjutkan kekuasaan dinasti Bani Umayyah. Dinamakah khilafah Abbasiyah karena pendiri dan penguasa dinasti ini adalah keturunan al-Abbas paman Nabi Muhammad SAW. Dinasti Abbasiyah didirikan oleh Abdullah al-Saffah ibn Muhammad ibn Ali ibn Abdullah ibn Abbas. Kekuasaannya berlangsung dalam rentang waktu antara tahun 132-656 H/750-1258 M. ${ }^{9}$ Selama dinasti ini berkuasa, pola pemerintahan yang diterapkan berbeda-beda sesuai dengan perubahan politik, sosial, dan budaya. Berdasarkan perubahan pola pemerintahan dan politik itu, para sejarawan membagi masa pemerintahan Bani Abbas menjadi lima periode: ${ }^{10}$

1. Periode Pertama (132H/750 M - 232 H/847 M), disebut periode pengaruh Persia pertama

2. Periode Kedua (232 H/847 M - 334H/945 M), disebut masa pengaruh Turki pertama.

3. Periode Ketiga (334 H/945 M - 447 H/1055 M), masa kekuasaan dinasti Buwaih dalam pemerintah khalifah Abbasiyah. Periode ini disebut juga masa pengaruh Persi kedua.

4. Periode Keempat (447 H/1055 M - 590 H/1194 M), masa kekuasaan dinasti Seljuk dalam pemerintahan khalifah Abbasiyah, masa ini disebut juga dengan masa pengaruh Turki kedua.

\footnotetext{
9 A. Syalaby, Sejarah dan Kebudayaan Islam III, (Jakarta: Pustaka Al Husna, 2003), 17

10 Bojena Gajane Atryzewska Sebagaimana dikutip Badri Yatim, Sejarah Peradaban Islam, (Jakarta: Raja GrafindoPersada, 2000), hlm: 49-50
} 
5. Periode Kelima (590 H/1194 M - 656 H/1258 M), masa khalifah bebas dari pengaruh dinasti lain, tetapi kekuasaannya hanya efektif di sekitar kota Bagdad.

Secara umum faktor-faktor berdirinyan daulah Abbasiyah dapat dijelaskan sebagai berikut:

1. Banyak terjadi perselisihan intern antara Bani Umayyah pada dekade tahun pemerintahannya.

2. Pendeknya masa .jabatan Khalifah diakhir-akhir pemerintahan Bani Umayyah, seperti khalifah Yazid bin AlWalid yang memerintah sekitar 6 bulan.

3. Jumlah putra mahkota lebih dari 1 orang seperti yang dilakukan oleh Marwan bin Muhammad yang menjadikan anaknya Abdullah dan Ubaidillah sebagai putra mahkota.

4. Bergabungnya sebagian afrad keluarga Umayyah kepada mazhab-nmazhab yang tidak benar menurut syari'ah.

5. Hilangnya kecintaan rakyat pada akhir-akhir pmerintahan Bani Umayyah.

6. Kesombongan pembesar-pembesar Bani Umayyah pada ahkuir pemerintahannya.

7. Timbulnya dukungan dari Al-Mawali (non Arab) ${ }^{11}$

Pada periode pertama pemerintahan Bani Abbas mencapai masa keemasannya. Secara politis, para khalifah betul-betul tokoh yang kuat dan merupakan pusat kekuasaan politik dan agama. Di sisi lain, kemakmuran masyarakat mencapai tingkat tertinggi. Periode ini juga berhasil menyipakan landasan bagi perkembangan filsafat dan ilmu pengetahuan Islam. Namun, periode ini sangat singkat hanya empat tahun.

Popularitas daulat Abbasiyah mencapai puncaknya pada zaman khalifah Harun al-Rasyid (786-809 M) dan puteranya alMa'mun (813-833 M). Menurut as-Sayuti bahawa zaman pemerintahan Khalifah Harun al-Rasyid seluruhnya merupakan zaman yang penuh dengan kabaikan, semuanya indah seperti pengantin-pengantin baru. ${ }^{12}$ Kekeyaan banyak dimanfaatkan oleh Harun al-Rasyid untuk keperluan sosial, rumah sakit, lembaga pendidikan dokter dan farmasi didirikan, disamping itu, pemandian-pemandian umum juga dibangun. Tingkat kemakmuran

11 Samsul Nizar (ed), Sejarah Pendidikan Islam: Menelusuri Jejak Sejarah Pendidikan Era Rasulullah Sampai Indonesia (Jakarta: KencanaPrenada Media Group), 66

12 A. Syalabi, Sejarah dan Kebudayaan Islam III, (Jakarta: Pustaka Al Husna, 2003), 98 
yang paling tinggi terwujud pada zaman khalifah ini. Kesejahteraan sosial, kesehatan, pendidikan, ilmu pengetahuan, kebudayaan serta kesusasteraan berada pada zaman keemasannya. Al-ma'mun sebagai pengganti Harun al-Rasyid dikenal sebagai khalifah yang cinta ilmu pengetahuan, sehingga pada masa pemerintahannya penerjrmahan buku-buku asing digalakkan. Beliau juga banyak mendirikan sekolah, salah satu karya besarnya yang terpenting adalah pembangunan bait al-Hikmah sebagai pusat penerjemahan yang berfungsi sebagai perguruan tinggi dengan perpustakaan yang terbesar. Pada masa al-Ma'mun inilah Bagdad menjadi pusat ilmu pengetahuan.

\section{Bentuk Kurikulum Pada Masa Dinasti Abbasiyah}

Kurikulum dalam pendidikan Islam pada waktu itu tentunya tidak sama dengan kurikulum modern. Menurut Ahmad Tafsir, kurikulum adalah sejumlah mata pelajaran yang harus ditempuh atau dipelajari oleh siswa. Lebih luas lagi kurikulum bukan hanya sekedar rencana pelajaran, tetapi semua yang secara nyata terjadi dalam proses pendidikan di sekolah. ${ }^{13}$ Pada lembaga pendidikan saat ini, siswa dituntut untuk mempelajari sejumlah bidang studi yang ditawarkan oleh lembaga. Disamping itu, siswa juga diwajibkan mengikuti serangkaian kegiatan sekolah yang dapat memberikan pengalaman belajar.

Pada waktu itu, kurikulum yang terdapat di lembaga pendidikan Islam tidak menawarkan mata pelajaran yang bermacam-macam. Dalam suatu jangka waktu, pengajaran hanya penyajikan satu mata pelajaran yang harus ditempuh oleh siswa. Sesudah materi tersebut selesai, baru ia diperbolehkan mempelajari materi yang lain, atau yang lebih tinggi tingkatannya. Misalnya pada tahap awal siswa diharuskan belajar baca-tulis, berikutnya ia belajar berhitung dan seterusnya.

Kurikulum dalam lembaga pendidikan pada masa klasik pada mulanya berkisar pada bidang studi tertentu. Namun seiring perkembangan sosial dan kultural, materi kurikulum menjadi semakin luas. Pada masa nabi di Madinah, materi pelajaran berkisar pada belajar menulis, membaca Al-Qur'an, keimanan, ibadah, akhlak, dasar ekonomi, dasar politik dan kesatuan. ${ }^{14}$

Setelah wilayah Islam semakin luas, Islam harus bersentuhan dengan budaya masyarakat non-Islam yang menyebabkan permasalahan social semakin komples. Problem social tersebut

\footnotetext{
${ }^{13}$ Ahmad Tafsir, Ilmu Pendidikan dalam Perspektif Islam, (Bandung: Rosdakarya, 1992), 53

${ }^{14}$ Ibid, 59
} 
pada akhirnya berpengaruh besar terhadap kehidupan keagamaan dan intelektual Islam, termasuk ilmu Hellenistik yang terjalin kontak dengan Islam. Perkembangan kehidupan intelektual dan kehidupan keagamaan dalam Islam membawa situasi lain bagi kurikulum pendidikan Islam. Maka diajarkanlah ilmu-ilmu baru seperti Tafsir, Hadits, Fiqih, Tata Bahasa, Sastra, Matematika, Teologi, Astronomi dan Kedokteran. ${ }^{15}$

Pada zaman kejayaan Islam, mata pelajaran bagi kurikulum sekolah tingkat rendah adalah Al-Qur'an dan agama, membaca, menulis dan syair, juga ditambahkan nahwu, cerita dan berenang. Dalam kasus-kasus lain di khususkan untuk membaca Al-Qur'an dan mengajarkan sebagian prinsip-prinsip pokok agama. Sedangkan untuk anak-anak amir atau penguasa, kurikulum tingkat rendah agak berbeda. Di istana-istana biasanya ditegaskan pentingnya pengajaran khitabah, ilmu sejarah, cerita perang, caracara pergaulan, disamping ilmu-ilmu pokok seperti Al-Qur'an syair dan fiqih. ${ }^{16}$ Kurikulum pendidikan dalam Islam bersifat fungsional, tujuannya mengeluarkan dan membentuk manusia muslim, yang kenal agama dan Tuhannya, berakhlak Al-Qur'an.

Hal ini seperti yang telah dilakukan oleh Harun al-Rasyid dalam mengajukan rencana pelajaran bagi puteranya (al-Amin) dengan mengatakan sebagai berikut: "Aku percayakan anakku, buah hatiku, kepadamu, aku berikan kepadmu kekuasaan untuk menguasainya. Buat dia agar taat kepadamu. Kupercayakan kedudukan penting ini padamu. Ajarkanlah kepadanya al-Qur;an, sejarah, syair, hadits dan pidato. Jangan beri dia kesempatan bersendagurau kecuali pada saat-saat tertentu. Didik dia agar menaruh hormat kepada pemuka-pemuka Bani Hasyim dan memperlakukan dengan baik komando-komando militer jika mereka menghadap kepadanya. Jangan biarkan waktu berlalu tanpa mengajaran bagi dia, tetapi jangan membuat dia bersedih. Jangan terlalu baik kepadanya karena dia akan malas. Perlakukanlah dia dengan lemah lembut, tetapi jika itu tidak mempan perlakukanlah dia dengan kekerasan". ${ }^{17}$

Setelah usai menempuh pendidikan tingkat rendah, siswa bebaas memilih bidang studi yang ingin di dalam pada tingkat tinggi. Jika ia ingin mendalami fiqih, ia harus belajar fiqih kepada

\footnotetext{
15 Hanun Asrohah, Sejarah Pendidikan Islam, (Jakarta: Logos, 1999), 73

16 Hasan Langgulung, Asas-Asas Pendidikan Islam cet II, (Jakarta: Pustaka AlHusna, 1992), 118

17 HanunAsrohah, Sejarah Pendidikan Islam, (Jakarta: Logos, 1999), 82 lihat juga Zuhairini dkk, Sejarah Pendidikan Islam, 93
} 
ulama fiqih yang ia kehendakai. Jika hendak mendalami hadits, ia mesti beguru pada ulama-ulama hadits. Seperti kasus al-Bukhari, semula beliau belajar ilmu fiqih kepada Muhamad bin al-Hasan, tetapi setalah Muhammad bin al-hasan melihat bahwa ilmu hadits lebih sesuai bagi al-Bukhari, gurunya menyarankan agar al-Bukhari belajar hadits saja. ${ }^{18}$

Ilmu-ilmu agama mendominasi kurikulum di lembagalembaga pendidikan formal, seperti di mesjid dan Al-Qur'an sebagai intinya. Ilmu-ilmu agama harus dikuasai agar dapat memahami dan menjelaskan secara terinci makan Al-Qur'an yang berfungsi sebagai fokus pengajaran. Selain itu, hadits dan tafsir juga penting bagi siswa yang ingin mengusai ilmu keagamaan. Hadits merupakan mata pelajaran dalam kurikulum yang paling penting, karena kedudukannya sebagai sumber agama yang kedua setelah Al-Qur'an. Hadits banyak diminati oleh penuntut ilmu sehingga pelajar hadits tidak hanya berlangsung di mesjid-mesjid tepai juga di rumah-rumah ulama dan tempat-tempat ulum. ${ }^{19}$

Seperti halnya ilmu hadits, ilmu fiqih juga banyak diminati pelajar. Pelajaran fiqih adalah materi kurikulum paling populer, mereka yang ingin mencapai jabatan-jabatandalam pengadilan tentunya harus memilih untuk mendalam bidang studi ini.

Seni berdakwah (retorika) juga membentuk bagian penting dalam pengajaran ilmu-ilmu agama, karena kemapuan menyampaikan dakwah denagn meyakinkan dan pelajaran ilmiah memainkan peranan penting dalam kehidupan keagamaan dan pendidikan Islam di kalangan masyarakat muslim. Keterampilan untuk bsrbicara di depan publik termasuk ke dalam pengalaman pendidikan yang sangat berharga dalam dunia pendidikan di masa klasik. $^{20}$

\section{Pembagian Kurikulum Pada Masa Dinasti Abbasiyah}

\section{A. Kurikulum Pendidikan Rendah/ Dasar}

Pada periode Abbasiyah sekolah dasar disebut juga (kuttab) yang merupakan bagian terpadu dengan mesjid. Kurikulum utamanya disebutkan pada al-Qur'an sebagai bacaan utama para siswa, mereka juga diajari baca-tulis. Hampir dalam seluruh kurikulum yang diajarkan, metode menghafal sangat dipentingkan. Lembaga pendidikan Islam pertama untuk pengajaran yang lebih

\footnotetext{
18 Ahmad Syalaby, Sejarah Pendidikan Islam (Terj) Muchtar Jahja dan Sanusi Latief, (Jakarta: Bulan Bintang, 1973), 299

${ }^{19}$ HanunAsrohah, loc.cit., 75

20 Charles Michael Staton, Pendidikan Tinggi dalam Islam: Ssjarah dan Peranannya dalam Kemajuan Ilmu Pengetahuan, (Jakarta: Logos, 1994), 53
} 
tinggi tingkatannya adalah Bait al-Hikmah (rumah kebijaksanaan) yang didirikan oleh al-Ma'mun di Bagdad. Selain berfungsi sebagai biro penerjemahan, lembaga ini juga dikenal sebagai pusat kajian akademis dan perpustakaan umum serta memiliki sebuah observatorium. ${ }^{21}$

Mata pelajaran pokok yang terdapat pada phase rendah adalah Al-Qur'an, agama, membaca, menulis dan syair. Dalam beberapa hal kadang-kadang ditambah dengan mata pelajaran anNahwu, cerita-cerita dan belajar berenang. Adapula diantaranya kurikulum yang berisi pelajaran yang terbatas pada menghafal AlQur'an dan mengajarkan beberapa dasar-dasar pokok agama.

Tentang pentingnya mengajarkan al-Qur'an pada anak usia dini atau pada phase rendah ini, seperti yang diungkapkan oleh Ibn Sina yang mengemukakan pendapatnya tentang mendidik anak, yaitu dimulai dengan mengjarkan Al-Qur'an, karena anak-anak telah siap dari segi fisik dan mental untuk menerima pendiktean, dan pada waktu yang sama pula diajarkan huruf hija' dan diajarkan dasar agama,kemudian mempelajari syair dan artinya, yang dimulai dengan Buhur Rajaz kemudian diajarkan qasidah. Apabila anak-anak telah selesai menghafal Al-Qur'an dan mengetahui dasar-dasar bahasa, kemudian ia diarahkan untuk mempelajari sesuatu sesuai dengan tabiatnya dan kesanggupannya. ${ }^{22}$

Al-Qabishy juga menjelaskan sebuah bentuk dari pendidikan tingkat pertama (rendah) dengan memulai mempelajari Al-Qur'an, sembahyang dan sesudah itu diperbolehkan mempelajari berhitung, syair, nalar dan bahasa arab.

Ibn Khuldun mengemukakan pentingnya mengajarkan AlQur'an bagi anak-anak. Mengajarkan Al-Qur'an itu adalah titik permulaan dan dasar pendidikan yang terisi dalam seluruh kurikulum di seluruh negara. Mengajarkan Al-Qur'an bagi anakanak merupakan salah satu syiar agama Islam. Menurut Ibn Khuldun sistem pengajaran yang dipakai di Maqhrib membatasi pada mempelajari Al-Qur'an, anak-anak tidak diajari hadits, fiqih natupun syair, sehingga mereka hanya mahir dalam Al-Qur'an saja. Berbeda dengan sistem pengajaran di Maqhrib, pembelajaran di Andalus dimulai dengan mempelajari Al-Qur'an karena Al-Qur'an dianggap sebagai sumber agama dan ilmu pengetahuan. Disana

\footnotetext{
21 Philip K. Hitti, History of The Arabs, (Jakarta: Serambi, 2005), 512-515

22 Asma Hasan Fahmi, Sejarah dan Filsafat Pendidikan Islam, (Jakarta: Bulan Bintang, 1979), 59-60
} 
juga diajarkan syair, bahasa Arab dan qawaidnya, ilmu khath dan membaca ........23

Dari berbagai pendapat para ulama' diatas, terlihat betapa pentingnya mengajarkan al-Qur'an bagi anak-anak pada usia dini, dan merupakan langkah awal dalam proses pembelajaran terhadap anak pada pendidikan phase rendah dan merupakan titik awal dasar pendidikan pengenalan agama Islam.

Adapun di Afrika disamping mempelajari Al-Qur'an, mereka juga mempelajari hadits, ilmu pengetahuan dan beberapa masalah yang menyangkut dengannya. Akan tetapi perhatian mereka lebih banyak ditekankan pada mempelajari Al-Qur'an dan menghafalnya, dan mempelajari riwayat dan qiraat-qiraatnya dari pada pelajaranpelajaran yang lain. Adapun perhatian mereka terhadap ilmu khath menduduki nomor dua setelah Al-Qur'an.

Menurut Mahmud Yunus, ilmu-ilmu yang di ajarkan pada tingkat rendah (kuttab) pada mulanya adalah sangat sederhana, yaitu: a). Belajar membaca dan menulis; b). Membaca Al-Qur'an dan menghafalnya; c). Belajar pokok-pokok ajaran Islam, seperti cara berwudhu', sembahyang puasa dan sebagainya. Pada masa khalifah Umar bin Khattab beliau instruksikan pada pendudukpenduduk kota supaya diajarkan pada anak-anak berenang, mengendarai kuda, memanah, membaca dan menghafal syair-syair dan peribahasan. ${ }^{24}$

Adapun rencana pengajaran (kurikulum) pada tingkat rendah secara umum adalah sebagai berikut: a). Membaca Al-Qur'an dan menghafalnya; b). Pokok-pokok agama Islam; c). Menulis; d). Kisah atau riwayat orang-orang besar Islam; e). Membaca dan menghafal syair-syair dan natsar (prosa);f). Berhitung; g). Pokok-pokok nahwu dan syorrof. ${ }^{25}$

Menurut keterangan al-Qabishy, bahwa mata pelajaran paka tingkat rendah terdiri dari dua macam, yaitu mata pelajaran wajib dan mata pelajaran ikhtiarah. Mata pelajaran wajib terdiri dari AlQur'an, sembahyang, do'a, nahwu dan bahasa Arab serta membaca dan menulis. Adapun mata pelajaran ikhtiariah terdiri dari: berhitung, ilmu nahwu dan bahasa Arab, sya'ir dan riwayat/tarikh Arab. ${ }^{26}$

\footnotetext{
23 Asma Hasan Fahmi, Sejarah dan Filsafat Pendidikan Islam, (Jakarta: Bulan Bintang, 1979), 61-62

24 Mahmud Yunus, Sejarah Pendidikan Islam, (Jakarta:Hidakarya Agung, 1992), 40

25 Mahmud Yunus, Sejarah Pendidikan Islam, (Jakarta:Hidakarya Agung, 1992), 49

${ }^{26}$ Ibid, 50
} 
Demikian rencana pelajaran (kurikulum) pada tingkat rendah di abad ke-4 H. Pendeknya kurikulun yang seperti itu umumnya dilakukan di sekolah-sekolah tingkat rendah di seluruh Negara Islam.

Pada masa itu pengajaran diberikan kepada murid-murid, seorang demi seorang dan belum berkelas-kelas seperti sekarang ini. Pada waktu itu, juga belum ada kitab-kitab yang ditetapkan mengajarkannya seperti sekarang, karena memang pada masa itu belum ada percetakatan modern untuk mencetak buku-buku. Pelajaran diberikan dengan dibacakan oleh guru dan diulang-ulang membacanya oleh murid, atau diditekan oleh guru dan ditulis oleh murid, atau murid tersebut disuruh menyalinn dari buku yang telah ditulis dengan tangan.

Dalam sistem yanmg biasa berlaku pada masa itu, mata pelajaran-mata pelajaran tersebut di atas, bukan diajarkan sekaligus kepada murid-murid, melainkan diajarkan satu persatu. Misalnya mula-mula diajarkan Al-Qur'an saja, setelah tamat atau hafal, baru diajarkan pokok-pokok nahwu/syaraf. Kemudian diajarkan mata pelajaran yang lain dan begitulah seterusnya.

\section{B. Kurikulum Pendidikan Menengah}

Kurikulum tingkat menengah juga tidak sama di berbagai daerah, namun secara umum kurikulum tingkat menengah itu dapat dipaparkan sebagai berikut: a). Al-Qur'an; b). Bahasa Arab dan kesusteraan; c). Fiqih; d). Tafsir; e). hadits; f). Nahwu/syaraf/balaqhah; g). Ilmu-ilmu pasti; h). Mantiq; i). Falak; j). Tarikh/sejarah; k). Ilmu-ilmu alam; l). kedokteran; m). Musik. ${ }^{27}$

Yaqut mengatakan rencana pelajaran pada tingkat menengah terdiri dari Al-Qur'an, tafsir, fiqih, nahwu, sastra, syair, berhitung , ilmu ukur, tarikh dan hadits. Selain itu ada lagi pelajaran menengah kejuruan. Misalnya untuk jadi juru tulis di kantor-kantor, selain dari belajar bahasa, ia harus belajar surat-menyurat, pidato, diskusi, berdebat, serta mempelajri tulisan indah.

\section{Kurikulum Pendidikan Tinggi}

Kurikulum untuk perguruan tinggi ada beberapa macam, sebagaimana pada tingkat dasar. Para mahasiswa tidak terkait dengan mempelajari sejumlah mata pelajaran tertentu. Kurikulum dalam pendidikan tinggi dibagi kedalam dua bagian pokok, yaitu:

27 Ibid, 55 
kurikulum agama ditambah dengan sastra dan kurikulum ilmu pengetahun ditambah dengan sastra. ${ }^{28}$

Di lembaga pendidikan tinggi teologi dan ilmu hadits dijadikan sebagai lansadan kurikulum dan metode pengajarannya lebih menekankan pada metode hafalan. Pada waktu itu, ketika catatan harian atau memoranda belum membudaya, kemampuan menghafal dikembangkan setinggi mungkin dengan syarat sumbersumber yang dihafal merupakan sumber-sumber yang dapat dipercaya. ${ }^{29}$

Al-Khuwarizmi meringkas kurikulum agama ditambah sastra dalam buku Miftahul 'Ulum sebagai berikut: ilmu fiqih yang membicarakan tentang sembahyang, puasa, zakat, perkawinan, penjualan, pembelian dan lain-lain. Ilmu nahwu, ilmu kalam, menulis, ilmu 'arudh dan ilmu akhbar terutama tentang sejarah Persi, sejarah Islam, sejarah Yunani dan Romawi. ${ }^{30}$

Kurikulum ilmu pengetahuan ditambah sastra merupakan cirri khas pashe kedua dari perkembangan pikiran dalam Islam, pada phase ini kelihatan jelas perkembangan kebebasan berpikir dan luasnya lapangan pembahasan. Ilmu pengetahuan yang dipelajri berupa ilmu matematika, ilmu alam, filsafat, kedokteran dan musik.

Pada masa itu, penentuan kurikulum pendidikan Islam berada di tangan ulama atau kelompok orang yang berpengaruh dan diterima sebagai otoritatif dalam soal-soal agama dan hukum. Ilmu-ilmu agama mendoninasi kurikulum lembaga pendidikan tinggi dan Al-Qur'an sebagai intinya. Disiplin-disiplin lain yang perlu untuk memahami dan menjelaskan makna Al-Qur'an tumbuh sebagai bagian inti dari pengajaran, seperti ilmu hadits dan ilmu tafsir. ${ }^{31}$

Charles Michael S berkesimpulan bahwa sepanjang masa klasik Islam, penentuan sistem dan kurikulum pendidikan berada di tangan ulama, kelompok orang yang berpengetahuan dan diterima sebagai otoritatif dalam soal-soal agama dan hukum, bukan ditentukanoleh struktur kekuasaan yang berkuasa.

Jadi, dapat disimpulkan secara umum, sistem pengelolaan pendidikan klasik tampaknya lebih ditentukan oleh kekuataan ulama (orang yang memiliki komitmen intelektual) dari pada

\footnotetext{
28 Asma Hasan Fahmi, Sejarah dan Filsafat Pendidikan Islam (Jakarta: Bulan Bintang, 1979), 75

${ }^{29}$ Philip K. Hitti, History of The Arabs, (Jakarta: Serambi, 2005), 518

${ }^{30} \mathrm{Ibid}, 78$

31 Charles Michael Staton, Pendidikan Tinggi dalam Islam: Sejarah dan Peranannya dalam Kemajuan Ilmu Pengetahuan, (Jakarta: Logos, 1994), 53
} 
kekuatan negara (orang yang memiliki kekuasaan). Baik pada masa Nabi maupun pda masa bani Abbasiyah, para tokoh agama memiliki otoritas untuk menenttukan sistem pendidikannya.

Cakupan kurikulum lembaga pendidikan tinggi Islam pada abad ke-10 dapat diketahui dari kitab Al-Fihrist (indeks) oleh Ibn al-Nadim pada tahun 988. Sumber kedua adalah karya-karya Ikhwan al-Shafa. Adapun ensiklopedi pengajaran yang dikemukana oleh Ikhwan al-Shafa adalah sebagai berikut: ${ }^{32}$

Disiplin-disiplim umum: tulis baca, arti kata dan gramatika, ilmu hitung, sastra: sajak dan puisi, ilmu tyentang tanda-tanda dan isyarat, ilmu sihir dan jimat, kimia, sulap, dagang dan keterampilan tangan, jual beli, komersial, pertanian dan peternakan, serta biografi dan kisah-kisah.

Ilmu-ilmu agama: ilmu Al-Qur'an, tafsir, hadits, fiqih, dzikir, zuhud, tasawuf dan syahadah.

Ilmu-ilmu filosofis: matematika, logika, ilmu angka-angka, geometri, astronomi, musik, aritmatika dan hokum-hukum geometri; ilmu-ilmu alam dan antropologi; zat, bentuk, ruang, waktu dan gerakan; kosmologi; produksi, peleburan, dan elemenelemen; meteorology dan mineorologi; esensi alam dan manifestasinya, botani, zoology, anatopmi dan antropologi.

Menurut Mahmud Yunus umumnya dalam perguruan tinggi itu terdiri dari dua jurusan, yaitu: jurusan ilmu-ilmu agama dan bahasa Arab serta kesusasteraannya atau disebut ilmu naqliyah dan jurusan ilmu-ilmu hikmah/ filsafat atau ilmu-ilmu 'aqliyah. 33

Ilmu-ilmu yang diajarkan pada jurusan ilmu naqliyah sebagai berikut: tafsir Al-Qur'an, hadits, fiqih dan usul fiqh nahwu/saraf, balaghah, bahasa Arab dan kesusasteraannya. Adapun ilmu-ilmu yang diajarkan pada jurusan ilmu 'aqliyah sebagai berikut: mantic, ilmu-ilmu alam dan kimia, musik, musik, ilmu-ilmu pasti,ilmu ukur, falak, ilahiyah (keTuhanan), ilmu hewan, ilmu tumbuh-tumbuhan dan kedokteran.

\section{Analisis Implementasi Kurikulum Pada Masa Dinasti Abbasiyah}

Di masa klasik, kurikulum yang terdapat di lembaga pendidikan Islam tidak menawarkan mata pelajaran yang bermacam-macam. Dalam suatu jangka waktu, pengajaran hanya penyajikan satu mata pelajaran yang harus ditempuh oleh siswa.

\footnotetext{
32 Ibid, 56

33 Mahmud Yunus, Sejarah Pendidikan Islam, (Jakarta:Hidakarya Agung, 1992), 57
} 
Sesudah materi tersebut selesai, baru ia diperbolehkan mempelajari materi yang lain, atau yang lebih tinggi tingkatannya. Misalnya pada tahap awal siswa diharuskan belajar baca-tulis, berikutnya ia belajar berhitung dan seterusnya.

Kurikulum dalam lembaga pendidikan pada masa klasik pada mulanya berkisar pada bidang studi tertentu. Namun seiring perkembangan social dan kultural, materi kurikulum menjadi semakin luas. Pada masa Nabi di Madinah, materi pelajaran berkisar pada belajar menulis, membaca Al-Qur'an, keimanan, ibadah, akhlak, dasar ekonomi, dasar politik dan kesatuan. ${ }^{34}$

Menurut hemat penulis, kurikulum klasik itu terkesan bersifat separate-subject curriculum, dimana setiap mata pelajaran berdiri sendiri-sendiri dan terpisah-pisah dari materi dan pengetahuan yang lain, sehingga kurikulum seperti ini cenderung berpusat pada materi pelajaran tanpa memperhatikan minat dan bakat, dan keperlun peserta didik.

Kurikulum bentuk ini cenderung statis dan ketinggalan zaman, kadang-kadang buku-buku yang dijadikan pegangan penyusunannya dilakukan beberapa tahun atau bahkan puluhan tahun yang lalu dan jika tidak dilakukan revisi untuk keperluan penyesuaian akan ketinggalan zaman. Kadang-kadang ada hal yang dianggap benar pada waktu itu tidak lagi diakui kebenarannya kini, sesuatu yang dulu belum ada, sekarang telah ada atau ditemukan, dan sebagainya.

Jika bentuk kurikulum seperti ini yang digunakan, hal ini bertentangan dengan bentuk kurikulum modern yang menekankan correlated curriculum bahkan integrated curriculum, dimana Kurikulum dengan bentuk ini menyajikan berbagai materi pelajaran menjadi satu seakan-akan merupakan mata rantai yang saling terkait.setiap mata rantai darinya harus bertalian dengan yang sebelumnya atau dibangaun atas suatu rantai yang sebelumnya. Oleh sebab itu dalam setiap pengajaran terlebih dahulu harus dimulai dengan mengingat kembali pelajaranpelajaran yang telah lalu.

Kalau kita perhatikan lebih cermat lagi, kurikulum klasik khususnya pada halaqah-halaqah dan sekolah diorganisasi berdasarkan pengajaran yang terpisah-pisah. Setiap ilmu mempunyai halaqat dan gurunya sendiri, dan setiap kitab mempunyai spesialisasi dalam ilmu tertentu. Kemudian pelajar

\footnotetext{
${ }^{34}$ Ahmad Tafsir, Ilmu Pendidikan dalam Perspektif Islam, (Bandung: Rosdakarya, 1992), 59
} 
yang ingin mempelajari beberapa ilmu harus memasuki beberapa halaqah.

Jika kita memahami secara mendalam kitab-kitab yang dipelajari pada halaqah-halaqah itu, kita akan mengetahui bahwa ilmu apapun dari ilmu-ilmu Islam pada waktu itu mempuanyai hubungan yang erat dengan ilmu-ilmu yang lain, dan kitab-kitab Islam yang pernah dipelajari masih tetap menjadi bukti tentang hal itu.

Sebagai contoh, kitab tafsir misalnya, dalam kitab tersebut bisa dikatakan penuh dengan berbagai i'rab dalam ilmu nahwu dan i'lal dalam ilmu sharaf. Tafsir Jalalain yang penuh dengan ratusan i'rab dan i'lal dan kitab ini merupakan kitab klasik. Jadi, bisa dikatakan bahwa kurikulum pada masa klasik itu bersifat integrated curriculum.

Keterpisahan mutlak antara berbagai materi pelajaran tidaklah termasuk tabiat pendidikan Islam. Oleh sebab itu seluruh ilmu ini harus berhubungan satu sama lain. Hal ini sesuai dengan prinsip kurikulum yang diajukan oleh Abdurrahman an-Nahlawi bahwa secara keseluruhann struktur dan organisasi kurikulum itu hendaknya tidak bertentangan dan tidak menimbulkan pertentangan. ${ }^{35}$ Pendekatan yang digunakan adalah pendekatan secara multidimensional yang mempradugakan suatu interrelasi dan koordinasi di antara belbagai bidang studi serta pokok bahasan yang diberikan kepada siswa. Demikian kurikulum harus tersusun secara berkesinambungan dan saling terkait dan terintegrasi. Antara bidang studi yang satu dengan yang lainnya hendaknya jelas pertautannya, saling mengacu, serta terikat benang merahnya.

Ketika pendidikan mengacu pada bentuk separate subject curriculum, maka bentuk yang seperti ini kurang relevan untuk diterapkan masa modern ini ini, Sebagaimana yang disampaikan oleh S. Nasution bahwa Kurikulum yang disusun dalam bentuk terpisah-pisah itu lebih bersifat subject-centered, berpusat pada bahan pelajaran dan mengabaikan minat dan keinginan siswa. Kurikulum ini disusun berdasarkan teori habitus, yang beranggapan bahwa keperibadian siswa itu dapat terbentuk berdasarkan potongan-potongan pengetahuan. Berdasarkan pandangan tersebut, kepribadian yang utuh dapat dibentuk berdasarkan sejumlah pengetahuan yang diperoleh secara

35 Abdurrahman An-Nahlawi, Prinsip-Prinsip dan Metode Pendidikan Islam, (Bandung: CV. Diponegoro, 1992), 275 
terpisah. $^{36}$ Penulis melihat bahwa kurikulum klasik itu juga berbentuk integrated curriculum, yang mengaitkan antara satu materi dengan materi yang seperti pada kitab tafsir Jalalain yang mengaitkan ilmu nahwu, i'rab dan i'lal.

Menurut hemat penulis, kurikulum (rencana pelajaran) yang tawarkan pada masa klasik masih relevan untuk ajarkan pada masa saat ini, namun perlu diintegrasikan antara mata pelajaran yang satu dengan yang lain, sehingga tidak terjadi pemisahan antar mata pelajaran. Dimana ilmu-ilmu agama mendominasi kurikulum di lembaga-lembaga pendidikan pada saat itu, seperti di mesjid dan Al-Qur'an sebagai intinya. Pengajaran Al-Qur'an menjadi inti kurikulum klasik baik pada tingkat rendah maupun pendidikan tinggi. Selain itu juga diajarkan ilmu-ilmu Tafsir, Hadits, Fiqih, Tata Bahasa, Sastra, Matematika, Teologi, Astronomi, Kedokteran. Ekonomi, Politik, Ilmu Falak, Mantik, Tarikh dan Musik. Hal ini sesuai dengan kurikulum modern yang menawarkan berbagai disiplin ilmu pengetahuan.

\section{Kesimpulan}

Dinasti Abbasiyah menjadi salah satu dinasti yang berhasil membawa umat Islam berada di Puncak Keemasan di segala bidang, terutama dalam bidang pendidikan. Dengan memperhatikan bentuk kurikulum pada masa dinasti Abbasiyah menjadi salah satu bukti bahwa pendidikan pada masa itu sudah mulai berkembang pesat. Hal itu juga ditunjukkan dengan klasifikasi kurikulum yang berbeda pada masing-masing tingkatan pendidikan dimana pemerintah dinasti Abbasiyah sangat memperhatikan kemampuan pemahaman peserta didik.

Sebagaimana yang sudah disampaikan diatas, bahwa kurikulum pada masa Dinasti Abbasiyah terbagi menjadi tiga : dasar, menengah dan atas. Dalam kurikulum pendidikan dasar, siswa diajarkan a). Belajar membaca dan menulis; b). Membaca AlQur'an dan menghafalnya; c). Belajar pokok-pokok ajaran Islam, seperti cara berwudhu', sembahyang puasa dan sebagainya. Sedangkan kurikulum pendidikan menengah a). Al-Qur'an; b). Bahasa Arab dan kesusteraan; c). Fiqih; d). Tafsir; e). hadits; f). Nahwu/syaraf/balaqhah; g). Ilmu-ilmu pasti; h). Mantiq; i). Falak; j). Tarikh/sejarah; k). Ilmu-ilmu alam; l). kedokteran; m). Musik. Dan kurikulum untuk pendidikan tinggi meliputi kurikulum agama ditambah dengan sastra dan kurikulum ilmu pengetahun ditambah

${ }^{36}$ S. Nasution Hlm. 80 
dengan sastra. Kurikulum agama yang dimaksud meliputi teologi, ilmu hadits dan ilmu fiqh.

Dengan adanya perbedaan implementasi kurikulum pada setiap tingkat pendidikan pada dinasti Abbasiyah, hal itu bisa dijadikan tolak ukur dalam implementasi kurikulum pada masa sekarang.

\section{Daftar Pustaka}

Ahmad, M. Pengembangan Kurikulum, (Bandung: Pustaka Setia, 1998)

An-Nahlawi, Abdurrahman. Prinsip-Prinsip dan Metode Pendidikan Islam, (Bandung: CV. Diponegoro, 1992)

Arikunto, Suharsimi. Prosedur Penelitian: Suatu Pendekatan Praktek. (Jakarta: Renika Cipta. Cet XII, .2002)

Asrohah, Hanun. Sejarah Pendidikan Islam, (Jakarta: Logos, 1999)

Hasan Fahmi, Asma. Sejarah dan Filsafat Pendidikan Islam, (Jakarta: Bulan Bintang, 1979)

Hitti, Philip K. History of The Arabs. (Jakarta: Serambi, 2005)

Langgulung, Hasan. Asas-Asas Pendidikan Islam. Jakarta: Pustaka

Al-Husna. Cet II, 1992)

Michael Staton, Charles. Pendidikan Tinggi dalam Islam: Ssjarah dan

Peranannya dalam Kemajuan Ilmu Pengetahuan, (Jakarta: Logos, 1994)

Moeleong, Lexy. Metode Penelitian Kualitatif, (Bandung: Remaja Rosdakarya, 1993)

Nasution,S. Pengembangan Kurikulum, (Bandung: Citra Aditya, 1993)

Nawawi, Hadari dan Mimi Martini. Penelitian Terapan, (Yogyakarta:

Gajah Mada University Press, 1994)

Nizar, Samsul (ed), Sejarah Pendidikan Islam: Menelusuri Jejak

Sejarah Pendidikan Era Rasulullah Sampai Indonesia (Jakarta:

KencanaPrenada Media Group, 2007)

Soehartono, Irawan. Metode Penelitian Social, (Bandung:Remaja Rosdakarya, 1999)

Susanto, Musyrifah. Sejarah Islam Klasik: Perkembangan Ilmu Pengetahuan Islam. (Jakarta: Kencana, 2003)

Syalaby, Ahmad. Sejarah Pendidikan Islam (Terj) Muchtar Jahja dan

Sanusi Latief, (Jakarta: Bulan Bintang, 1973)

Syalaby, A. Sejarah dan Kebudayaan Islam III. Jakarta: Pustaka Al Husna, 2003)

Syaodih Sukmadinata, Nana. Pengembangan Kurikulum: Teori dan Praktek, (Bandung: Remaja Rosdakarya, 1997) 
Tafsir, Ahmad. Ilmu Pendidikan dalam Perspektif Islam, (Bandung: Rosdakarya, 1992)

Yatim, Badri. Sejarah Peradaban Islam, (Jakarta: Raja Grafindo Persada, 2000)

Yunus, Mahmud. Sejarah Pendidikan Islam, (Jakarta: Hidakarya Agung, 1992)

Zuhairini dkk, Sejarah Pendidikan Islam, Jakarta: Direktorat Jenderal Pembinaan Kelembagaan Agama Islam. Cet II, 1986) 